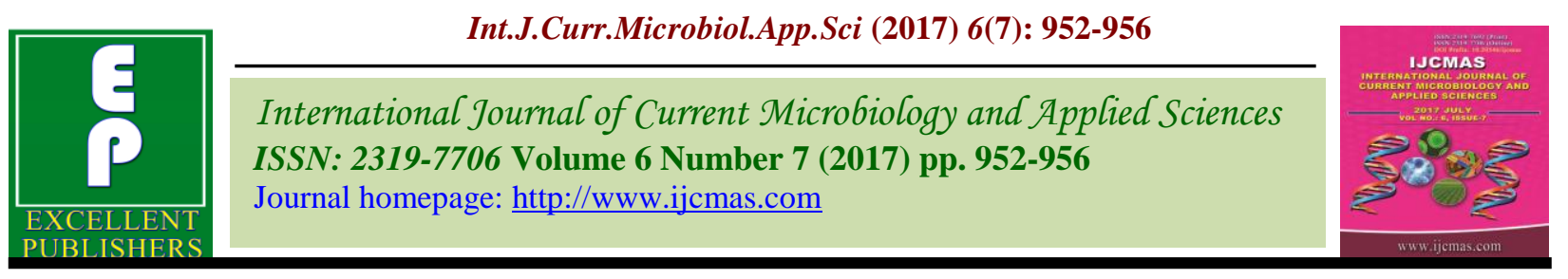

Original Research Article

https://doi.org/10.20546/ijcmas.2017.607.116

\title{
Assessment of Economic Injury Level (EIL) due to Holotrichia fissa Brenske on Groundnut under Greenhouse and Field Conditions
}

\author{
R.G. Shrilakshmi ${ }^{1}$ and R.R. Patil ${ }^{2}$ \\ ${ }^{1}$ Department of Agricultural Entomology, College of agriculture, Dharwad, India \\ ${ }^{2}$ University of Agriculture sciences, Dharwad- 580005, Karnataka, India \\ *Corresponding author
}

\begin{tabular}{|c|c|}
\hline & A B S T R A C T \\
\hline \multicolumn{2}{|l|}{ Keywords } \\
\hline $\begin{array}{l}\text { EIL, Holotrichia } \\
\text { fissa, Groundnut, } \\
\text { Green house. }\end{array}$ & \multirow{3}{*}{$\begin{array}{l}\text { Present study was carried out at two locations, the green house experiment } \\
\text { was carried at Main Agricultural Research Station, Dharwad and field } \\
\text { experiment was carried at Hattarawata (Belgaum district) in kharif- season } \\
\text { during } 2014-15 \text {.The results showed that Economic Injury Level (EIL) for } \\
\text { H. fissa in groundnut was } 1.03 \text { grubs per } 0.24 \mathrm{~m}^{2} \text { area under green house } \\
\text { conditions and } 1.00 \text { grubs per } \mathrm{m}^{2} \text { area under field conditions. }\end{array}$} \\
\hline Article Info & \\
\hline $\begin{array}{l}\text { Accepted: } \\
\text { 14 June } 2017 \\
\text { Available Online: } \\
\text { 10 July } 2017\end{array}$ & \\
\hline
\end{tabular}

\section{Introduction}

White grubs (Coleoptera: Scarabaeidae) are soil inhabiting and root feeding immature stages of scarab beetles. The white grub family, Scarabaeidae is the second largest family within the order Coleoptera. The world fauna of white grub exceeds 30,000 species (Mittal, 2000) and there are about 1300 North American species Borror et al., The maximum number occurs in the tropical areas of the world, particularly in African and Oriental regions. The fauna of the Indian subregion is very rich and diverse but it is yet to be fully explored (Mishra and Singh, 1999). White grub larvae cause severe damage to groundnut as well as other commercial crops like potato, sugarcane, pea, maize etc., whereas for plants like bajra, sorghum and maize have adventitious root system can withstand much. The affected plants show varying degrees of yellowing, wilting and death (Rai et al., 1969). The affected plants can be pulled up easily. Patches of dead plants are seen throughout the field which later coalesces to produce intensive areas of damage (Veeresh, 1977). In endemic areas, the damage to groundnut ranges from 20-100 per cent. One grub/m $\mathrm{m}^{2}$ may cause $80-100$ per cent plant mortality (Yadava,1995). White grubs also damage pods causing direct yield losses (Anitha, 1992). There are two white grub species which are major pests of groundnut in India. These are Holotrichia consanguinea Blanchard and Holotrichia serrata (Fabricius). Holotrichia consanguinea 
is the key white grub pest in the northern parts of the country and finds loose sandy, well drained soil to be quite suitable for its survival and multiplication. It is the dominant white grub species in the states of Rajasthan, Gujarat, Haryana, Punjab, Uttar Pradesh and Bihar. H. serrata is dominant in Karnataka, Maharashtra, Andhra Pradesh and Tamil Nadu and survives in well drained heavy, red alluvial and black cotton soils (Yadava, 1991). In recent times $H$. fissa is emerging as a major pest on groundnut and other crops under rain-fed situations of Belagavi district. H. fissa was economically important and found in large numbers as compared to other species in Hattarwat village of Chikkodi taluk on ber. Groundnut, soybean, maize and paddy were infested by $H$. fissa and $H$. serrata (Tippannavar and Patil, 2013). Therefore, there is a need to evolve suitable management strategy to tackle this pest under rain fed conditions. Hence, the present study was under taken to assess the EIL for H. fissa on groundnut under greenhouse and field conditions.

\section{Materials and Methods}

\section{Mass rearing of $H$. fissa}

The adult beetles of $H$. fissa were collected immediately after first rains from endemic areas of Chikkodi and Hukkeri taluks and used to get grubs of known instar and age to asses EIL in the laboratory as well as under field condition. The field collected beetles were brought to laboratory at UAS Dharwad and confined to big plastic crates $(0.24$ $\mathrm{m}^{2}$ ). Three fourth was filled with soil and organic matter in 1:1 proportion. Soil was kept moist by sprinkling water daily. Leafy branches of ber were provided in the crates as food for beetles. The eggs collected from moist soil later were transferred to the earthen crates containing soil and organic matter mixture. Later to these crates ragi (finger millet) seeds were sown to provide root material as food for the second and third instar grubs and were used for experimentation.

\section{Under green house condition}

A study was conducted for the estimation of Economic injury level (EIL) due to H. fissa under green house was in groundnut during 2014-15 cropping season, at MARS, Department of Entomology, UAS, Dharwad. The experiment was laid out as complete randomized block designs. The groundnut variety JL-24 was sown during July 18, 2014 with a crate size of $0.24 \mathrm{~m}^{2}$ following all the recommended package of practices except root grub management. Observations were made separately on per cent mortality of plants at 30, 40 and 60 days after sowing. In each treatment number of plants died due to grub attack was recorded. At harvest, pod yield per plot was recorded. The data obtained on different parameters were subjected to suitable statistical analysis.

\section{Under field condition}

Field experiment was conducted at Hattarawata village of Chikkodi taluka, Belagavi district during 2014-2015 cropping season in the farmer's field in groundnut crop. The groundnut local variety Western-6 was sown during July 20, 2014 in a micro plot size of $1 \times 1 \mathrm{~m}^{2}$ and gross plot of $28.2 \mathrm{~m}^{2}$ following all the recommended package of practices except white grub management. The lateral movement of grubs from one micro plot to another was prevented by putting $2 \mathrm{~mm}$ wire mesh barrier. There were seven treatments laid out in a randomized block design with three replications. The treatments (Different grub) were imposed on August 15, 2014. Different grub load per plots were released to know the EIL. The lateral movement of grubs from one micro plot to another was prevented 
by putting $2 \mathrm{~mm}$ wire mesh barrier. Plant mortality was recorded by counting the wilted plants. Observations similar to lab studies were followed for field trials.

Treatment details on number of grubs released per crate to assess the loss caused to groundnut crop at Dharwad during kharif- 2014

\begin{tabular}{|c|c|}
\hline $\begin{array}{l}\text { Treat } \\
\text { ments }\end{array}$ & $\begin{array}{c}\text { Grub load / } \\
\text { crate }\left(0.24 \mathrm{~m}^{2}\right)\end{array}$ \\
\hline $\mathrm{T}-1$ & One \\
\hline $\mathrm{T}-2$ & Two \\
\hline $\mathrm{T}-3$ & Three \\
\hline $\mathrm{T}-4$ & Four \\
\hline $\mathrm{T}-5$ & Five \\
\hline $\mathrm{T}-6$ & Six \\
\hline $\mathrm{T}-7$ & Control (no release) \\
\hline
\end{tabular}

(The treatment details were same for field condition experiment but no of grubs released per $1 \times 1 \mathrm{~m}^{2}$ )

\section{Results and Discussion}

\section{Green house conditions}

The regression equation $Y=0.58-0.18 x$ depicts the reduction of $0.18 \mathrm{q} / \mathrm{ha}$ pod yield was due to increase of one grub/crate. The economic injury level (EIL) computed till the harvest of the crop after sowing was 1.03 grubs per 0.24 $\mathrm{m}^{2}$ area. ETL was 0.34 grubs per $0.24 \mathrm{~m}^{2}$ (Table 1).

\section{Field conditions}

The regression equation $\mathrm{Y}=2.24-0.70 \mathrm{x}$ depicts the reduction of $0.70 \mathrm{q} / \mathrm{ha}$ pod yield due to increase of one grub $/ \mathrm{m}^{2}$. The economic injury level (EIL) computed till the harvest of the crop after sowing was 1.00 grubs per $\mathrm{m}^{2}$ area and ETL was 0.33 grubs per $\mathrm{m}^{2}$ (Table 2).

Present investigation revealed the Economic Injury Level (EIL) in green house and field conditions. EIL was $1.03 / 0.24 \mathrm{~m}^{2}$ and $1.00 / \mathrm{m}^{2}$ under green house and field conditions, respectively. Grub reduced groundnut yield by an average of $8 \mathrm{~g} /$ grub in untreated condition while, in case of treated it was lesser (4.5 g/grub) under green house conditions. Whereas under field conditions the yield reduction was $21 \mathrm{~g} / \mathrm{grub}$ under untreated conditions and $11.3 \mathrm{~g} / \mathrm{grub}$ under treated conditions. This is in agreement with the reports of John Rogers et al, 2005 according to whom, provisional EIL for Heteronyx piceus in groundnut was 1.67 larvae/ row metre (for crop yielding less than $1900 \mathrm{~kg} / \mathrm{ha}$ ) and 4.91 larvae/ row metre (for crop yielding more than $1900 \mathrm{~kg} / \mathrm{ha}(19 \mathrm{q} / \mathrm{ha})$. The yield reduced by 4.20 and $1.43 \mathrm{~g}$ per larva under crop yielding lees than and more than $1900 \mathrm{~kg} / \mathrm{ha}(19 \mathrm{q} / \mathrm{ha})$, respectively from Queensland. Further, the provisional EIL for H. serrata was 1 grub/7.1 $\mathrm{m}^{2}$ and reducing groundnut yield by an average of $7.52 \mathrm{~g} /$ larva under rainfed conditions of Andhra Pradesh.

The per cent yield loss caused in untreated condition was 13.51 and 9.63 over control under green house and field conditions, respectively. Losses in yield of groundnut caused by $H$. consanguinea and collar rot (caused by Aspergillus niger) were investigated in the field in Punjab, India, in 1978 and 1979. Granular formulations of phorate, carbofuran, isofenphos and fensulfothion at $1 \mathrm{~kg}$ a.i. per ha were highly effective against $H$. consanguinea, plant mortality being reduced from 10.7 per cent in untreated plots to $0.7-2.8$ per cent in treated ones. Collar rot was controlled with thiram. 
Table.1 Economic Injury Level (EIL) for Holotrichia fissa Brenske in groundnut under green house condition at Dharwad kharif-2014

\begin{tabular}{|c|c|c|c|c|c|c|c|}
\hline Treatments & $\begin{array}{l}\text { No. of grubs } \\
\text { released/ crate } \\
\left(0.24 m^{2}\right)(X)\end{array}$ & $\begin{array}{c}\text { Yield/ } \\
(\mathrm{kg} / \text { crate) }(\mathrm{Y})\end{array}$ & $\mathbf{X Y}$ & $\mathbf{X}^{2}$ & $\begin{array}{c}\text { Regression } \\
\text { Coefficient (b) }\end{array}$ & $\begin{array}{l}\text { EIL/ crate } \\
\left(0.24 m^{2}\right)\end{array}$ & $\begin{array}{r}\text { Regression } \\
\text { Equation } \\
(\mathbf{y})\end{array}$ \\
\hline $\mathrm{T}_{1}$ & 1.0 & 0.053 & 0.05 & 1.0 & \multirow{8}{*}{0.18} & \multirow{8}{*}{1.03} & \multirow{8}{*}{$Y=0.58-0.18 x$} \\
\hline $\mathrm{T}_{2}$ & 2.0 & 0.047 & 0.09 & 4.0 & & & \\
\hline $\mathrm{T}_{3}$ & 3.0 & 0.041 & 0.12 & 9.0 & & & \\
\hline $\mathrm{T}_{4}$ & 4.0 & 0.026 & 0.11 & 16.0 & & & \\
\hline $\mathrm{T}_{5}$ & 5.0 & 0.022 & 0.11 & 25.0 & & & \\
\hline $\mathrm{T}_{6}$ & 6.0 & 0.017 & 0.10 & 36.0 & & & \\
\hline \multirow[t]{2}{*}{$\mathrm{T}_{7}$} & No release & 0.062 & 0.00 & 0.0 & & & \\
\hline & $\Sigma 21.00$ & $\Sigma 0.27$ & $\Sigma 0.58$ & $\sum 91.0$ & & & \\
\hline \multicolumn{8}{|c|}{$\mathrm{ETL}=0.34$} \\
\hline
\end{tabular}

*Market price of the groundnut during the season ₹ 5000/q

*Cost of plant protection under protected condition: ₹ 11000/ha

*Cost of plant protection under unprotected condition: ₹ 9000/ha

Table.2 Economic Injury Level (EIL) for Holotrichia fissa Brenske in groundnut under field condition at Hattarawata kharif-2014

\begin{tabular}{|c|c|c|c|c|c|c|c|}
\hline Treatments & $\begin{array}{l}\text { No. of grubs } \\
\text { released } / \mathbf{m}^{2}(\mathbf{X})\end{array}$ & $\begin{array}{c}\text { Yield/ } \\
\left(\mathrm{kg} / \mathrm{m}^{2}\right)(\mathrm{Y})\end{array}$ & $\mathbf{X Y}$ & $\mathrm{X}^{2}$ & $\begin{array}{c}\text { Regression } \\
\text { Coefficient (b) }\end{array}$ & $\mathrm{EIL} / \mathbf{m}^{2}$ & $\begin{array}{c}\text { Regression } \\
\text { Equation } \\
(y)\end{array}$ \\
\hline $\mathrm{T}_{1}$ & 1.0 & 0.193 & 0.19 & 1.0 & \multirow{8}{*}{0.70} & \multirow{8}{*}{1.00} & \multirow{8}{*}{$\mathrm{Y}=2.24-0.70 \mathrm{x}$} \\
\hline $\mathrm{T}_{2}$ & 2.0 & 0.177 & 0.35 & 4.0 & & & \\
\hline $\mathrm{T}_{3}$ & 3.0 & 0.156 & 0.47 & 9.0 & & & \\
\hline $\mathrm{T}_{4}$ & 4.0 & 0.129 & 0.51 & 16.0 & & & \\
\hline $\mathrm{T}_{5}$ & 5.0 & 0.096 & 0.48 & 25.0 & & & \\
\hline $\mathrm{T}_{6}$ & 6.0 & 0.083 & 0.50 & 36.0 & & & \\
\hline \multirow[t]{2}{*}{$\mathrm{T}_{7}$} & No release & 0.215 & 0.00 & 0.0 & & & \\
\hline & $\sum 21.00$ & $\sum 1.05$ & $\sum 2.5$ & $\sum 91.0$ & & & \\
\hline \multicolumn{8}{|c|}{$\mathrm{ETL}=0.33$} \\
\hline
\end{tabular}

*Market price of the groundnut during the season ₹ 5000/q

*Cost of plant protection under protected condition: ₹ 11000/ha

*Cost of plant protection under unprotected condition: $₹ 9000 /$ ha 
The avoidable losses when $H$. consanguinea, collar rot and the two together were controlled with pesticides was estimated to be 28.74 40.34, 16.48 - 32.80 and 32.30 - 66.17 per cent, respectively (Bakhetia,1982).

In conclusion, EIL was 1.03 grubs per $0.24 \mathrm{~m}^{2}$ area under green house conditions and 1.00 grubs per $\mathrm{m}^{2}$ area under field conditions. It showed that one grub is enough to cause economic damage to plants especially under rainfed conditions.

\section{References}

Anitha, V. 1992. Studies on the groundnut pod borers. M.Sc, Thesis, Andhra Pradesh Agril. Univ., India.

Bakhetia, D.R.C. and Brar, K.S. 1985. The white grub problem in Punjab. Status paper presented at the 3rd workshop of All India Coordinated Research Project on white grubs, College of Agriculture, MPKV Kolhapur, 8-10 October, 1985, 1-6.

Borror, D.J., Delong, D.M. and Triplehorn, C.A. 1975. An introduction to the study of insects $\left(4^{\text {th }}\right.$ ed.). Chicago, Holt, Rinehart and Wilston, pp. 36-49.

John Rogers, Andrew, L.W., John, A. and Wightman. 2005. Damage credential of two scarab species on groundnut. Intl. J. Pest Mngt., 51(4): 305 -312.

Mishra, P.N. and Singh, M.P. 1999,
Determination of predominant species of white grubs in Garhwal Region of Uttar Pradesh Hills (India). J. Entomol. Res., 23(1): 65-69

Mittal, I.C. 2000. Survey of scarabaeid (Coleoptera) fauna of Himachal Pradesh (India). J. Entomol. Res., 24: 133-141.

Rai, B.K., Joshi, H.C., Rathore, Y.K., Dutta, S.M., and Shinde, V.K.R. 1969. Studies on the bionomics and control of white grub, Holotrichia consanguinea Blanch. in Lalsot district Jaipur, Rajasthan. Indian J. Entomol., 31(2): 132-142.

Tippannavar, P.S. and Patil, R.R., 2013, Species composition of white grubs in rainfed ecosystem of Karnataka, India. J. Exp. Zool. India, 16(2): 505-508.

Veeresh, G.K. 1977. Distribution and abundance of whitegrubs in relation to environment. In: Symposium on insect and environment, Delhi University, February, 21-23.

Yadava, C.P.S. and Sharma, G.K., 1995, Indian white grubs and their management. Technical bulletin No. 2. Project Co-ordinating Centre, AlCRP on white grubs, Durgapura, Jaipur, p. 26.

Yadava, C.P.S. 1991. White grub management in Groundnut. Technical Bulletin No.1. Project Co-ordinating Centre, AlCRP on white grubs. Agricultural Research Station, Durgapura, Jaipur, p. 14.

\section{How to cite this article:}

Shrilakshmi, R.G. and Patil, R.R. 2017. Assessment of Economic Injury Level (EIL) due to Holotrichia fissa Brenske on Groundnut under Greenhouse and Field Conditions. Int.J.Curr.Microbiol.App.Sci. 6(7): 952-956. doi: https://doi.org/10.20546/ijcmas.2017.607.116 